\title{
Karyotype variability in species of the genus Zephyranthes Herb. (Amaryllidaceae-Hippeastreae)
}

\author{
W. J. P. Felix $・$ L. P. Felix $\cdot$ N. F. Melo $•$ \\ M. B. M. Oliveira $\cdot$ J. H. A. Dutilh • \\ R. Carvalho
}

Received: 20 September 2010/Accepted: 2 May 2011/Published online: 28 May 2011

(c) The Author(s) 2011. This article is published with open access at Springerlink.com

\begin{abstract}
In this work, the cytotaxonomic implications of the chromosomal characterization of cultivated and native Zephyranthes species described in northeastern Brazil were studied. All individuals had karyotype formed by a set of metacentric chromosomes, in addition to submetacentric and acrocentric chromosomes. In Zephyranthes robusta, $2 n=12$ was observed and karyotype with formula $4 \mathrm{M}+$ 2SM in somatic cells, representing the most symmetric karyotype among the investigated species. Z. sylvatica showed three different chromosome complement numbers: $2 n=12$ with formula $1 \mathrm{M}+5 \mathrm{SM}, 2 n=12+1 \mathrm{~B}$ with
\end{abstract}

W. J. P. Felix

Mestrado em Melhoramento Genético de Plantas,

Departamento de Agronomia, UFRPE, Recife, PE, Brazil

e-mail: winstonpessoa@yahoo.com.br

\section{P. Felix}

Laboratório de Citogenética Vegetal, Departamento de Fitotecnia, Universidade Federal da Paraíba, Areia, PB, Brazil e-mail: 1pfelix@hotmail.com

\section{N. F. Melo}

Laboratório de Biotecnologia, Embrapa Semi-Árido,

Petrolina, PE, Brazil

e-mail: natoniel@cpatsa.embrapa.br

M. B. M. Oliveira

Departamento de Bioquímica, UFPE, Recife, PE, Brazil

e-mail: mbetaniam2008@hotmail.com

J. H. A. Dutilh

Departamento de Botânica, Instituto de Biologia,

Universidade Estadual de Campinas, Campinas, SP, Brazil

e-mail: capitani@unicamp.br

R. Carvalho $(\bowtie)$

Laboratório de Citogenética Vegetal, Departamento de Biologia/Genética, UFRPE, Recife, PE, Brazil

e-mail: reginaldo.ufrpe@gmail.com
$1 \mathrm{M}+5 \mathrm{SM}+(1 \mathrm{~B})$, and $2 n=18$ formed by cracks. The cultivated species $Z$. rosea Lindl. presented $2 n=24$ with $4 \mathrm{M}+7 \mathrm{SM}+1 \mathrm{~A}$, however $Z$. grandiflora Lindl. showed the same chromosome number with $2 \mathrm{M}+5 \mathrm{SM}+5 \mathrm{~A}$. Zephyranthes aff. rosea Lindl. presented $2 n=25$ with one small metacentric forming a crack in the fourth metacentric pair. Z. brachyandra has $2 n=24+$ (1B) and formula $4 \mathrm{M}+3 \mathrm{SM}+5 \mathrm{~A}+(1 \mathrm{~B})$. Z. candida Herb. presented $2 n=38$ and karyotype formula $9 \mathrm{M}+10 \mathrm{SM}$. In Habranthus itaobinus numerical variation was observed, with the majority of populations showing a chromosome complement composed of $2 n=44+1 \mathrm{~B}$ with $5 \mathrm{M}+12 \mathrm{SM}+5 \mathrm{~A}+$ (1B), or $2 n=44+3 \mathrm{~B}$ in a single population. Mechanisms involved in the formation of these karyotypes from chromosomal imbalance data are discussed. Taken together, data from this study only partially confirm previous counts for epithets and further enhance the cytological variability data previously reported for the genus.

Keywords Karyotype asymmetry - B chromosomes . Numerical variability $\cdot$ Habranthus itaobinus

\section{Introduction}

The genus Zephyranthes comprises approximately 65 species with neotropical distribution (Hutchinson 2003; Judd et al. 1999) with 36 species recognized for Brazil. Many of them are valued as ornamentals with relatively small flowers and short lifecycle (Lorenzi and Souza 1999). Some, such as $Z$. grandiflora, are used in herbal treatments (Kai et al. 2006); species such as $Z$. candida, Z. atamasco, and others are used as ornamentals, and as donors of resistance genes against aphids and homoptera (Pang et al. 2004). It is a karyologically variable group, with 
chromosome numbers between $2 n=10$ in Zephyranthes seubertii (Daviña 2001) and $2 n=200$ in a horticultural hybrid (Flory and Smith 1980). Chromosome records have been presented for about 50 species, with common occurrence of numerically unstable species, which can influence phenotype (Coe 1954). Species such as Z. candida with $2 n=38$, 40, and 41 (Raina and Khoshoo 1971) and Zephyranthes selberti from Argentina with $2 n=10,20$, 30, and 40 (Daviña and Fernández 1989) exemplify this variability. Moreover, in several species, it is common to find chromosomal heteromorphisms in karyotypes resulting from structural changes (Raina and Khoshoo 1971; Felix et al. 2008). The cytological variability in the genus has suggested the existence of three primary base numbers: $x=5, x=6$, and $x=7$ (Naranjo 1974; Daviña and Fernández 1989). Most species have karyotypes composed of one or a few long metacentric pairs and other smaller ones with median, submedian, subterminal, and terminal centromeres (Flory 1977).

The species Zephyranthes candida, Z. grandiflora, $Z$. robusta, Z. rosea, and Z. brachyandra are cultivated in Brazil for their ornamental potential (Dutilh 2005). The first three are native to south and southeast regions of Brazil, while Z. rosea is considered native to Central America and the Caribbean, but is spontaneous in southern and southeastern Brazil, and Z. brachyandra occurs in Argentina. Z. candida is a numerically variable species, currently restricted to Argentina population (Raina and Khoshoo 1971) or cultured. Z. rosea and Z. grandiflora are less variable and have polyploidy and aneuploidy events related to their karyotype evolution (Daviña 2001). However, Z. robusta and Z. brachyandra are numerically stable, with records of $2 n=12$ and 24 , respectively. The genus is represented in northeastern Brazil by a single species, Z. sylvatica, in addition to Habranthus bahiensis Ravenna and H. itaobinus Ravenna (Dutilh 2006; Oliveira 2006; Alves-Araújo et al. 2007); these latter two are usually included in the generic limits of Zephyranthes (Dutilh, personal communication). No previous karyological records are known for $H$. bahiensis and $H$. itaobinus, while recently a karyotypic study was performed for $Z$. sylvatica, observing the occurrence of cytotypes with $2 n=12,13$, and 18 in a single population (Felix et al. 2008).

This study aims to characterize the karyotype of six cultivated species of Zephyranthes (Z. candida, Z. grandiflora, Z. robusta, Z. rosea, Z. aff. rosea, and Z. brachyandra), comparing them with data in the literature. In addition to these, karyotypes of different populations of two species native to northeastern Brazil (Z. sylvatica and Habranthus itaobinus) are described, aiming to compare these data with each other and with prior information from literature in order to identify numerical and structural variations involved in the formation and maintenance of these karyotypes.

\section{Materials and methods}

Zephyranthes rosea and Z. aff. rosea were obtained from home gardens at Areia City, Paraíba State and Belém City, Pará State, while Z. grandiflora was collected from a spontaneous population in the Botanical Garden of São Paulo. Z. rosea presents clear-red to pink flowers, well open with short tube, erect stamens, all with same size and declined style, while $Z$. aff. rosea differs in presenting white flowers and wider tepals. Z. grandiflora has clearpurple flowers, and $Z$. candida has white flowers, and erect and semicylindrical leaves. $Z$. robusta and Z. brachyandra were obtained from plants grown at the Agronomy Institute of Campinas, São Paulo, while Z candida was provided by a private collector. The two species native to northeast Brazil were collected in the field from various populations. Table 1 summarizes field data and the main karyotype features of all species studied. All material was grown in the experimental garden of the Cytogenetics Laboratory, Center for Agricultural Sciences (CCA), Federal University of Paraíba (UFPB). The material was incorporated into the Herbarium Prof. Jayme Coelho de Moraes (EAN), CCA/UFPB.

For cytological analysis root tips were used, pretreated with $2 \mathrm{mM}$ 8-hydroxyquinoline for $4-8 \mathrm{~h}$ and subsequently fixed in 3:1 Carnoy (ethanol:glacial acetic acid) for $24 \mathrm{~h}$ and stored in a freezer until further analysis. The roots were first washed twice for $5 \mathrm{~min}$ in distilled water at room temperature, hydrolyzed for $20 \mathrm{~min}$ in $5 \mathrm{~N} \mathrm{HCl}$, squashed in $45 \%$ acetic acid, frozen in liquid nitrogen until coverslip removal, and conventionally stained with $2 \%$ Giemsa (Guerra 1983). To count and identify chromosome morphology, only closed cells and chromosomes with clearly visible centromere were considered and counted to calculate the mean size.

To identify the centromere position, the terminology suggested by Guerra (1986) was adopted: metacentric (M), submetacentric (SM), acrocentric (A), and telocentric (T), numerically defined by the branches ratio (r) obtained from the relationship between the long arms (1) and short arms (c) and the centromeric index (CI). Karyotype asymmetry was estimated from the classification of Stebbins (1971) and indices of Romero Zarco (1986) based on measurements of three well-scattered cells. Total chromosome length (TCL) and mean chromosome length (CL) were taken, and the mean centromeric index $(\mathrm{CI})$ and the ratio between longest and shortest chromosome (R) were also calculated. 


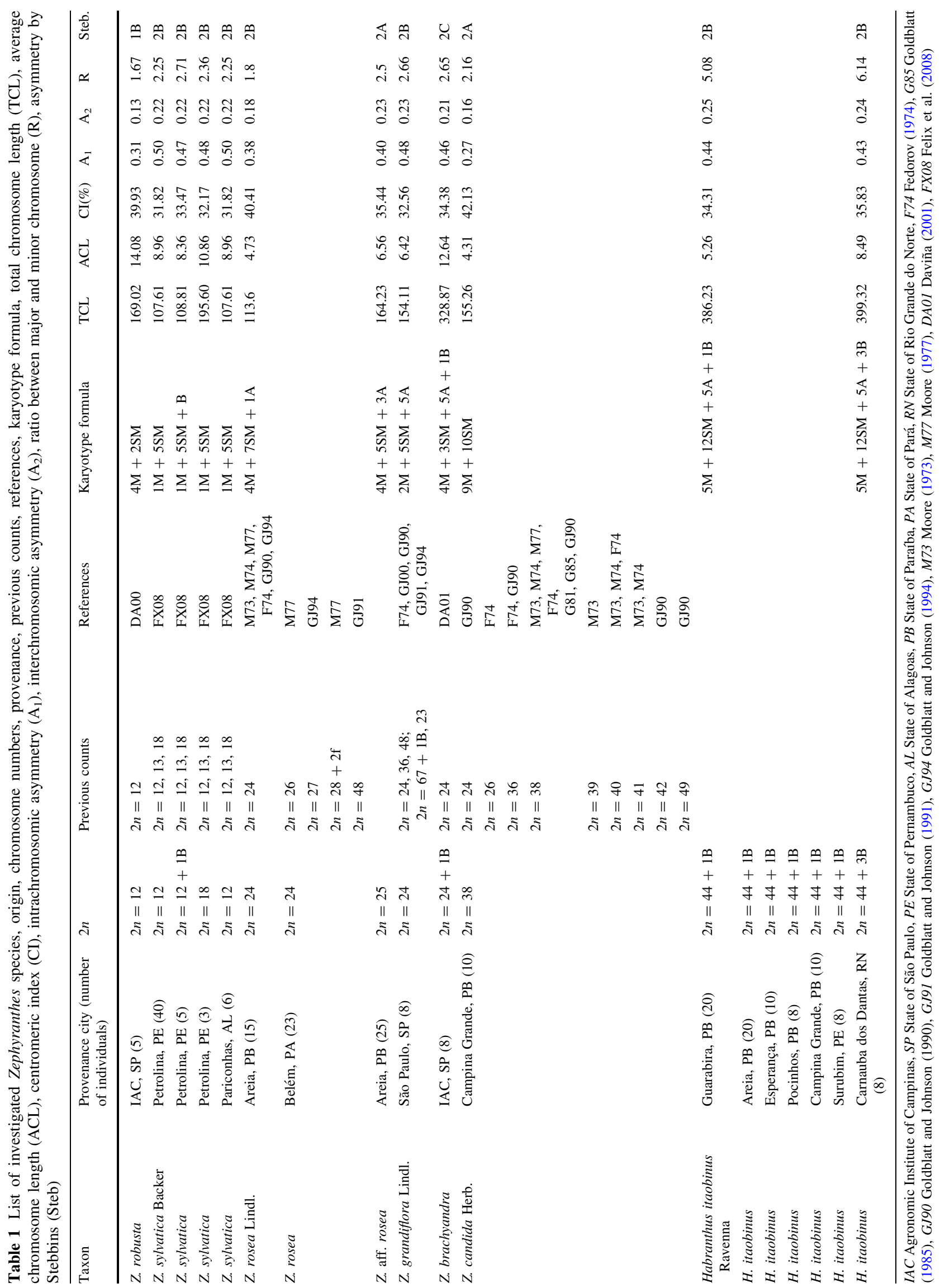




\section{Results}

All species showed karyotypes formed by a set of metacentric to submetacentric chromosomes and a smaller number of acrocentric chromosomes, with gradual reduction in size and chromosome morphology. However, different species had distinct karyotypic formula, although sometimes they coincided concerning ploidy level.

Somatic cells with $2 n=12$ and karyotype formula $4 \mathrm{M}+2 \mathrm{SM}$ were observed in Zephyranthes robusta. Metacentric pairs measured on average $17.7 \mu \mathrm{m}$ in the larger pair and $14.43 \mu \mathrm{m}$ in the smaller one, submetacentric gradually varied in size from 13.75 to $11.1 \mu \mathrm{m}$. The species presented $169.02 \mu \mathrm{m}$ total chromosome length, $14.08 \mu \mathrm{m}$ average chromosome length, 1.67 largest to smallest chromosome ratio, and $39.93 \%$ centromeric index, with intrachromosomal and interchromosomal asymmetries of 0.31 and 0.13 (Fig. 1a, b; Table 1). This species was included in the 2B classification category of Stebbins (1971), which corresponds to symmetric karyotypes.
In Zephyranthes sylvatica, the occurrence of three cytotypes with $2 n=12,12+1 \mathrm{~B}$, and 18 was confirmed. However, six individuals from Pariconhas always presented $2 n=12$. In the cytotype with $2 n=12$, the metacentric pair was heteromorphic with larger chromosome of $14 \mu \mathrm{m}$ and smaller one of $12 \mu \mathrm{m}$; submetacentric pairs gradually varied in size from 6 to $10 \mu \mathrm{m}$ (Fig. 1c, d). These individuals had $107.61 \mu \mathrm{m}$ total chromosome length, $8.96 \mu \mathrm{m}$ average chromosome length, 2.25 largest to smallest chromosome ratio, and $31.82 \%$ centromeric index, with intrachromosomal and interchromosomal asymmetries of 0.50 and 0.22 (Table 1), being included in the 2B classification category of Stebbins (1971). In cytotypes with $2 n=12+1 \mathrm{~B}$ (Fig. 1e, f) and $2 n=18$ (Fig. 1g, h), karyotype features were identical to those observed in normal diploid cytotype, except for the presence of a small metacentric B chromosome measuring $4.0 \mu \mathrm{m}$ (Fig. 1f) and the formation of slightly heteromorphic cracks for the chromosomal size in triploid (Fig. 1h).
Fig. 1 Giemsa-stained metaphase chromosomes of Zephyranthes robusta $2 n=12$ (a), karyogram of four metacentric pairs and two submetacentric pairs (b); Z. sylvatica $2 n=12$ (c), karyogram showing one metacentric pair and five submetacentric pairs (d), metaphase with $2 n=12+1 \mathrm{~B}$ (e), karyogram showing a metacentric pair, five submetacentric pairs, and one B supernumerary submetacentric chromosome (f), a triploid individual with $2 n=18(\mathbf{g})$, karyogram of the triploid showing a crack of metacentric and another five submetacentric chromosomes (h). Bars $10 \mu \mathrm{m}$

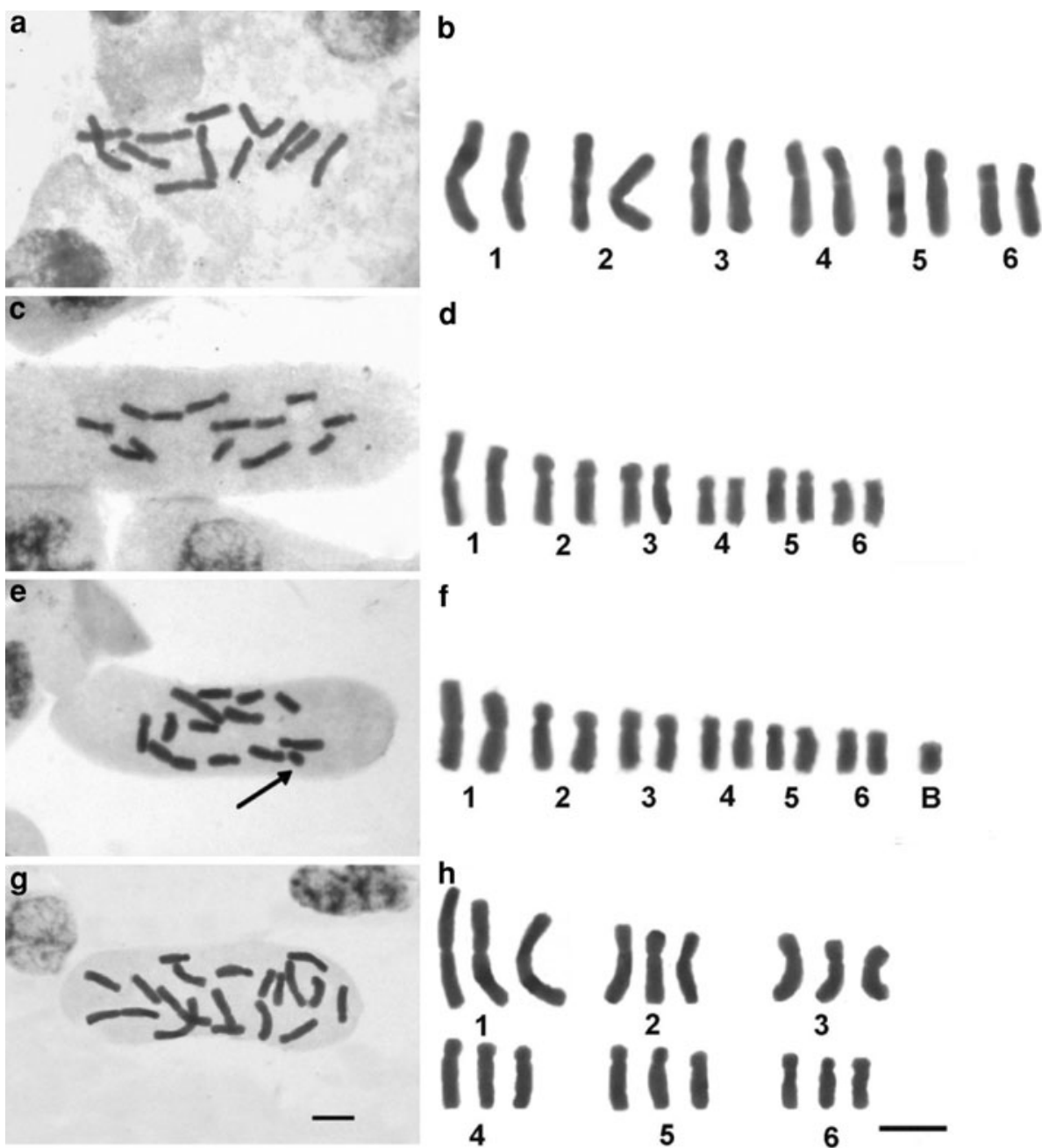


Somatic cells with $2 n=24$ and karyotype $4 \mathrm{M}+$ $7 \mathrm{SM}+1 \mathrm{~A}$ were observed in Zephyranthes rosea (Fig. 2a, b). Metacentric pairs measured on average $7.7 \mu \mathrm{m}$ in the larger pair and 5.6-4 $\mu \mathrm{m}$ in the smaller ones, submetacentric gradually varied in size from 3.5 to $6 \mu \mathrm{m}$, and the acrocentric about $5.0 \mu \mathrm{m}$. The species presented $113.6 \mu \mathrm{m}$ total chromosome length, $4.73 \mu \mathrm{m}$ average chromosome length, 1.8 largest to smallest chromosome ratio, and $40.41 \%$ centromeric index with intrachromosomal and interchromosomal asymmetries of 0.38 and 0.18 (Table 1). The species was included in the $2 \mathrm{~B}$ classification category of Stebbins (1971), which corresponds to relatively symmetric karyotypes.

Zephyranthes aff. rosea showed somatic cells with $2 n=25$ and karyotypes composed of four metacentric pairs, five submetacentric, and three acrocentric pairs. The first four pairs measured $10.4 \mu \mathrm{m}$ in the larger pair and 5.6-3.8 $\mu \mathrm{m}$ in the smaller ones, the latter probably forming a morphologically identical trisomic set (Fig. 2c-d) The set of submetacentric chromosomes was formed by two larger pairs (8.8 and $8.4 \mu \mathrm{m}$, respectively) and three smaller ones $(6.8-5.7 \mu \mathrm{m})$. Species presented $164.23 \mu \mathrm{m}$ total chromosome length, $6.56 \mu \mathrm{m}$ average chromosome length, 2.5 largest to smallest chromosome ratio, and $35.44 \%$ centromeric index. The intrachromosomal asymmetry was 0.40 , while the interchromosomal value was
0.23 , being included under the $2 \mathrm{~A}$ classification category of Stebbins (1971).

For species Zephyranthes grandiflora, we observed $2 n=24$ chromosomes (Fig. 2e) and karyotype with two metacentric, five submetacentric, and five acrocentric pairs with karyotypic formula $2 \mathrm{M}+5 \mathrm{SM}+5 \mathrm{~A}$ (Fig. 2f). The two metacentric pairs measured on average from 10.25 to $9.08 \mu \mathrm{m}$, the submetacentric $7.45-4.42 \mu \mathrm{m}$, and the acrocentric from 6.8 to $4.8 \mu \mathrm{m}$. The species presented $154.11 \mu \mathrm{m}$ total chromosome length, $6.42 \mu \mathrm{m}$ average chromosome length, 2.66 largest to smallest chromosome ratio, and $32.56 \%$ centromeric index, with intrachromosomal and interchromosomal asymmetries of 0.48 and 0.23 (Table 1). The species was included in the $2 \mathrm{~B}$ classification category of Stebbins (1971), which corresponds to relatively symmetric karyotypes.

Zephyranthes brachyandra revealed karyotype with $2 n=24+1 \mathrm{~B}$ and formula $4 \mathrm{M}+3 \mathrm{SM}+5 \mathrm{~A}+1 \mathrm{~B}$ (Fig $3 \mathrm{a}-\mathrm{c}$ ) with a pair of satellites observed in the short arms of the 11th acrocentric pair. Metacentric pairs measured on average $7.7 \mu \mathrm{m}$ in the larger pair and 5.6-4.0 $\mu \mathrm{m}$ in the smaller ones, submetacentric pairs gradually varied in size from 6 to $5 \mu \mathrm{m}$, the acrocentric measured about $5.0 \mu \mathrm{m}$, and the B chromosome $3 \mu \mathrm{m}$. The species presented $328.87 \mu \mathrm{m}$ total chromosome length, $12.64 \mu \mathrm{m}$ average chromosome length, 2.65 largest to smallest
Fig. 2 Giemsa-stained prometaphases and metaphase of Zephyranthes rosea $2 n=24$ (a); karyogram with three metacentric pairs, seven submetacentric, and one acrocentric chromosome pair (b); Z. aff. rosea showing $2 n=25$ (c), karyogram with four metacentric pairs (trisomy at pair number four), five submetacentric, and three acrocentric pairs (d); Z. grandiflora $2 n=24(\mathbf{e}, \mathbf{f})$. Bars $10 \mu \mathrm{m}$

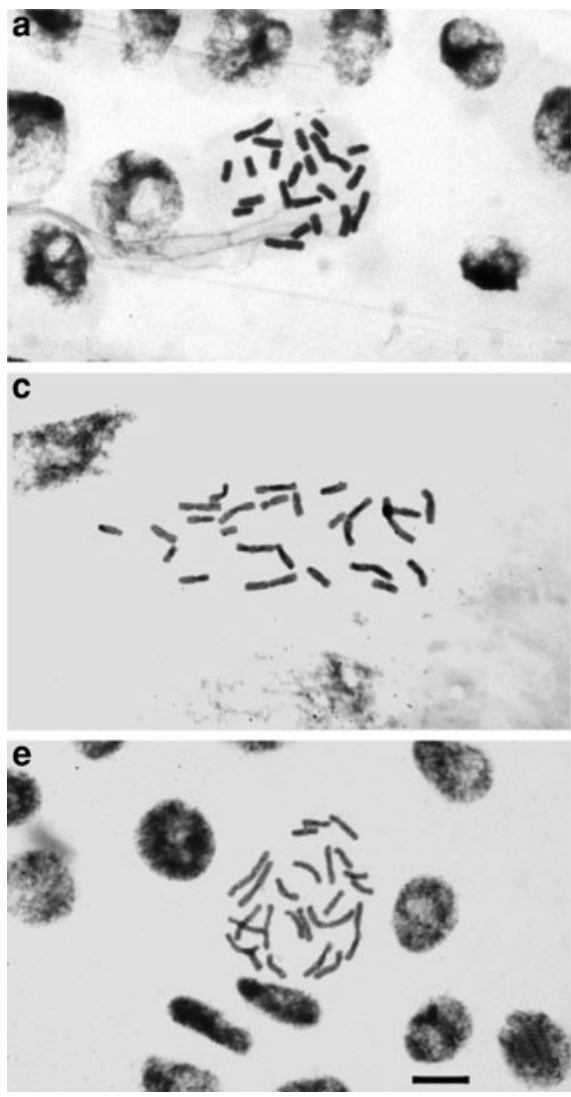

d
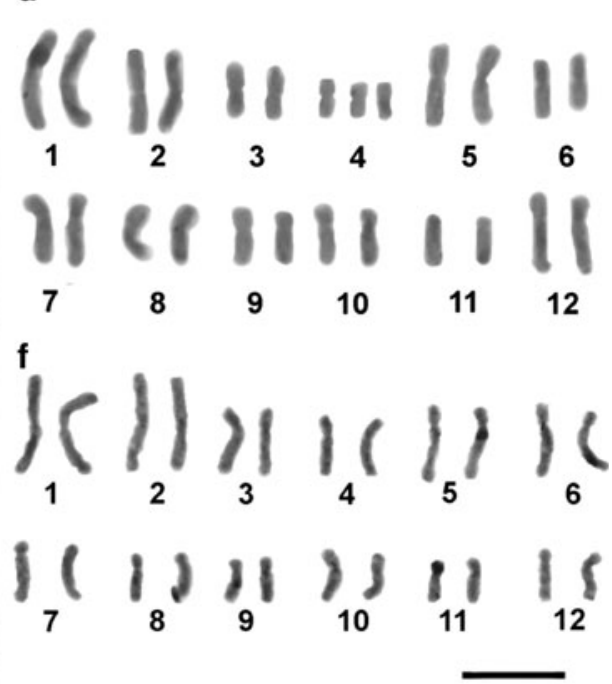
chromosome ratio, and $34.38 \%$ centromeric index with intrachromosomal and interchromosomal asymmetries of 0.46 and 0.21 (Table 1). The species was included in the 2C classification category of Stebbins (1971), which corresponds to relatively symmetric karyotypes.

Somatic cells with $2 n=38$ and karyotype with nine metacentric and ten submetacentric pairs were observed in Zephyranthes candida (Fig. $3 \mathrm{~b}-\mathrm{d}$ ). The first nine measured on average 5.91-3.28 $\mu \mathrm{m}$, while submetacentric pairs gradually ranged in size from 6.9 to $3.1 \mu \mathrm{m}$. The species presented $155.26 \mu \mathrm{m}$ total chromosome length, $4.31 \mu \mathrm{m}$ average chromosome length, 2.16 largest to smallest chromosome ratio, and $42.13 \%$ centromeric index equivalent, with intrachromosomal and interchromosomal asymmetries of 0.27 and 0.16 (Table 1), being included in the 2A classification category of Stebbins (1971).

For Habranthus itaobinus, six populations had $2 n=44+1 \mathrm{~B}$ (Fig. 4a), 5 metacentric, 12 submetacentric, and 5 acrocentric pairs (Fig. 4c) in all individuals analyzed. Metacentric pairs measured from 19 to $10 \mu \mathrm{m}$ in the three larger and 9-5 $\mu \mathrm{m}$ in the smaller metacentric, submetacentric pairs ranged from 9 to $4 \mu \mathrm{m}$, the acrocentric pairs ranged from 6 to $3 \mu \mathrm{m}$, and the supernumerary chromosome measured $2.0 \mu \mathrm{m}$, with $386.23 \mu \mathrm{m}$ total chromosome length, $5.26 \mu \mathrm{m}$ average chromosome length, 5.08 largest to smallest chromosome ratio, and $34.31 \%$ centromeric index, with intrachromosomal and interchromosomal asymmetries of $0.44-0.25$ (Table 1 ). The species was included in the $2 \mathrm{~B}$ classification category of Stebbins (1971). For this species, a single population from Carnauba dos Dantas, RN had a karyotype with $2 n=44+3 \mathrm{~B}$ (Fig. 4b) in all four individuals studied and karyotypic formula similar to the other populations, except for the higher number of metacentric B with $2 \mu \mathrm{m}$ (Fig. 4d).
These populations had $399.32 \mu \mathrm{m}$ total chromosome length, $8.49 \mu \mathrm{m}$ average chromosome length, 6.14 largest to smallest chromosome ratio, and $35.83 \%$ centromeric index, with intrachromosomal interchromosomal asymmetries of 0.43 and 0.24 (Table 1). The species was also included in the $2 \mathrm{~B}$ classification category of Stebbins (1971).

\section{Discussion}

All species with previous karyological data had divergent chromosome numbers, except $Z$. robusta that had the previous count of $2 n=12$ confirmed and Z. brachyandra, with $2 n=24+1 \mathrm{~B}$, which diverged from the single prior count of $2 n=24$ in this species, but no record of $B$ chromosome (Daviña 2001). The two karyotypes are remarkably similar, differing primarily by the presence of a supernumerary chromosome in the Brazilian population. In Z. sylvatica, only the population from Petrolina, PE, which had been previously studied, presented cytotype with supernumerary chromosomes and triploid individuals. The other population studied from Alagoas State had $2 n=12$ in all individuals. This discrepancy may be due to the small number of individuals studied when compared with the 48 individuals from Petrolina. In this species, individuals with $2 n=18$ showed no clear morphological differences compared with those diploids, indicating autotriploid origin for these individuals. Autopolyploids usually originate by accidental formation of unreduced gametes, which would originate triploid forms after fertilizing normal gametes (Stebbins 1971; Grant 1989; Bretagnolle and Thompson 1995). The occurrence of three autotriploid individuals seems to indicate that triploids are relatively frequent in
Fig. 3 Giemsa-stained metaphase chromosomes of Zephyranthes brachyandra $2 n=24+1 \mathrm{~B}(\mathbf{a})$, karyogram showing four metacentric, three submetacentric, five acrocentric, and one " $B$ " submetacentric chromosome (c); metaphase of Z. candida $2 n=38$ (b) and karyogram showing nine metacentric and ten submetacentric pairs (d). Bar $10 \mu \mathrm{m}$

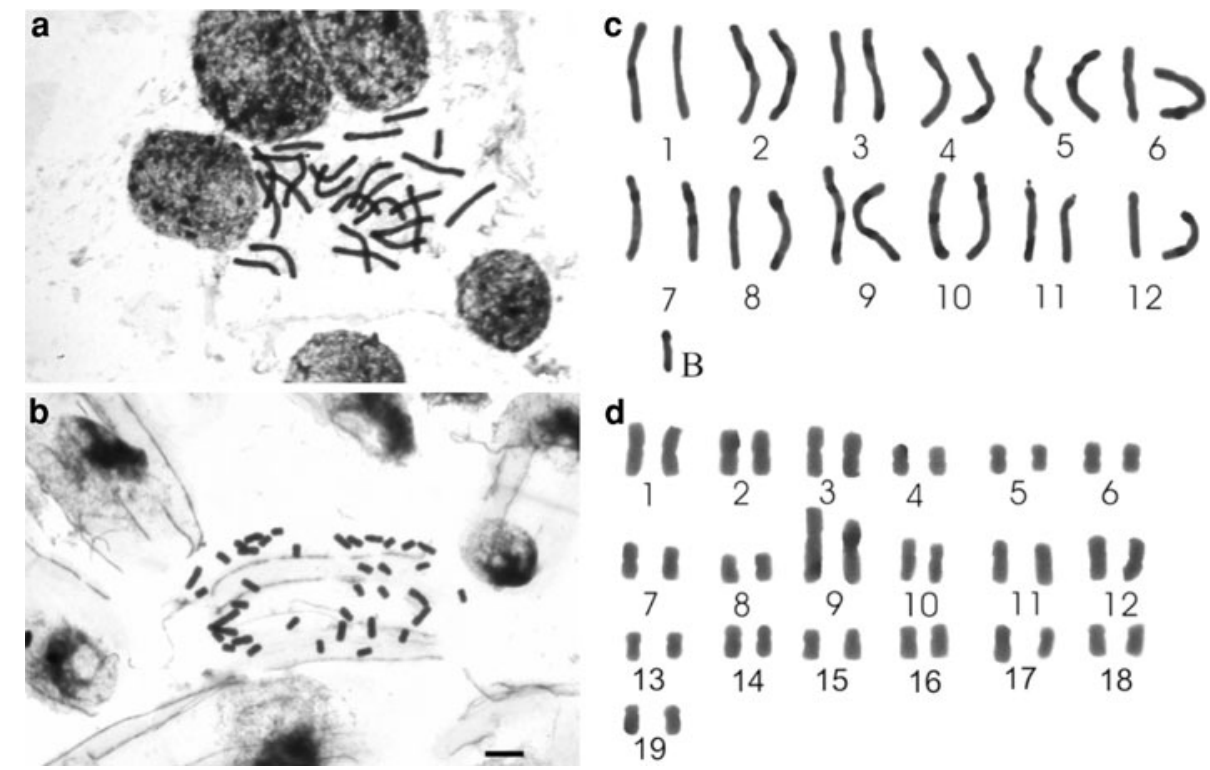


Fig. 4 Giemsa-stained metaphase chromosomes of Habranthus itaobinus showing $2 n=44+1 \mathrm{~B}(\mathbf{a})$ and $2 n=44+3 \mathrm{~B}(\mathbf{b})$; karyogram with 5 metacentric pairs, 12 submetacentric pairs, 5 acrocentric, plus $1 \mathrm{~B}$ and $3 \mathrm{~B}$ chromosomes (c-d). Arrows and arrowheads indicates B chromosomes. Bars $10 \mu \mathrm{m}$

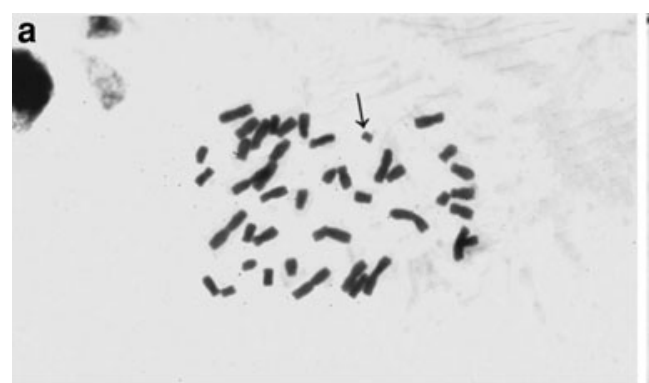

Ђ
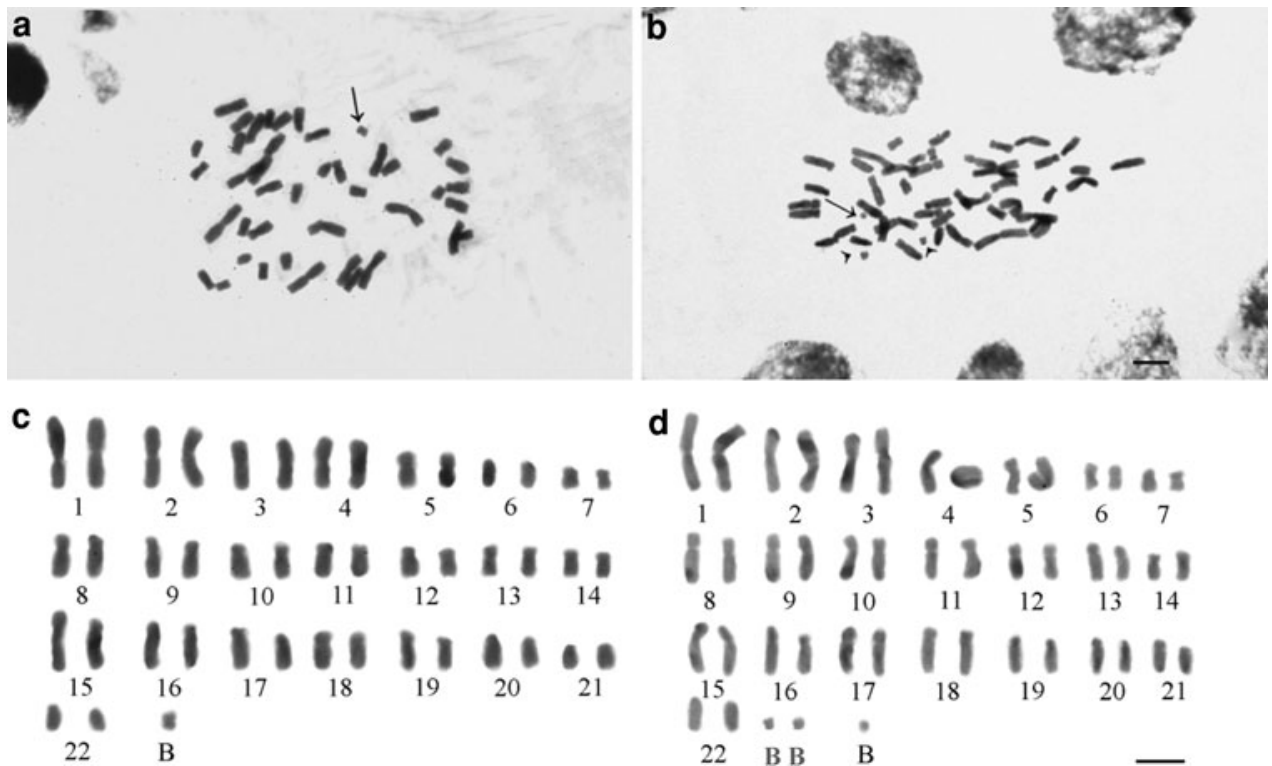

d

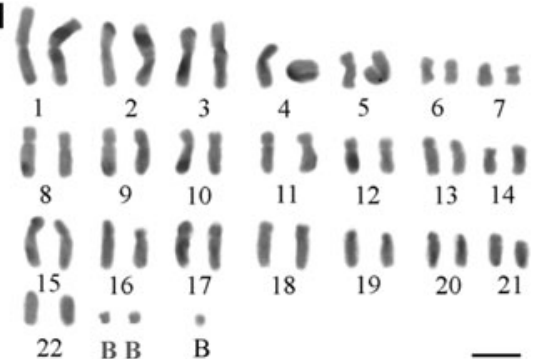

this population. The sterility of these hybrids could be circumvented by agametic production of seeds as in Z. brasiliensis Traub (Greizerstein and Naranjo 1987). In Nothoscordum gracile as N. fragrans (Alliaceae), an aneuploid with $2 n=19$, sterility has been overcome by widespread dissemination through joint production of adventitious and sexual embryos (Dyer 1967). Although autopolyploids are traditionally considered rare in nature (Grant 1989), data indicate that this event seems to be more frequent (Soltis and Soltis 1999) and of greater importance for karyological evolution of plants in general than commonly thought previously (Stebbins 1971; Grant 1989).

\section{B chromosomes in Zephyranthes}

Among the species studied, B chromosomes were observed in Z. sylvatica, Z. brachyandra, and Habranthus itaobinus, although the distribution of these supernumerary chromosomes among individuals within a same population showed different patterns between these species. In Z. sylvatica, from a total of 48 individuals, only 5 presented a B chromosome; all 76 individuals from six studied populations of $\mathrm{H}$. itaobinus carried a supernumerary chromosome, while in the population from Carnauba dos Dantas, RN all individuals had three B. In both cases, the supernumerary chromosomes were slightly more heteropycnotic than the others of the complement. Already in Z. brachyandra, the B chromosome occurred in eight individuals. B chromosomes have three universal properties (Jones and Houben 2003; Camacho 2000): (1) they are not essential to the host life, (2) they originate from A chromosomes of the same or another species, and (3) they are clearly differentiated from other A chromosomes, with which they do not recombine. These characteristics have led several authors to consider B as parasitic genomes. In the present sample, the B chromosome found in Z. sylvatica seems to fit perfectly into the general definition of $\mathrm{B}$ chromosomes, given their occasional frequency in a single population. However, the B chromosome seems to have some adaptive significance in H. itaobinus, since all studied individuals were carriers of at least one accessory chromosome. In Allium schoenoprasum (Alliaceae), a family related to the Amaryllidaceae, the presence of a B chromosome provided improvement in seed germination (Bougourd et al. 1994). However, in some species where B are clearly parasitic, their maintenance in the genome and increase in their number is obtained by meiotic drift, where there is preferential B segregation in one of the phases of meiosis or mitosis of pollen (Jones and Houben 2003). The identification of a single $\mathrm{B}$ chromosome in a few individuals of Z. sylvatica favors the hypothesis of a parasitic B chromosome, while the persistent presence of a B in all analyzed individuals of $H$. itaobinus seems to support the idea of an adaptive function of this chromosome.

The recognition of $\mathrm{B}$ chromosome is sometimes difficult when these chromosomes occur in pairs, as in Brachycome dichromosomatica of the Asteraceae family, where it was possible to recognize two pairs of B using specific B probes (Houben et al. 1997). In Cestrum intermedium (Solanaceae), B chromosome exhibited large terminal heterochromatic blocks, which were not observed in B chromosomes of two other species (Fregonezi 2004). In this sample, B chromosomes presented heterochromatic bands that enable differentiation from other chromosomes (data not shown), but the clear differentiation in size relative to the other chromosomes of the complement facilitates their recognition as supernumerary chromosomes. 


\section{Numerical chromosome variation}

The genera Zephyranthes and Habranthus vary considerably in terms of chromosome number, being considered polybasic genera, with $x=5,6$, and 7 for the former (Daviña and Fernández 1989) and $x=6,7,9,11,13$, and 15 for the latter (Naranjo 1969). In this sample, $x=6$ occurred in all Zephyranthes species, with $Z$. robusta and $Z$. sylvatica being diploid, Z. rosea, Z. aff. rosea, $Z$. grandiflora, and $Z$. brachyandra being tetraploid, and $Z$. candida, $2 n=38$, being a hexaploid with upward disploidy. The only species in which chromosome counting diverged from this basic number was Habranthus itaobinus, being hexaploid $x=7$ with upward disploidy. An interesting aspect of the chromosomal variation observed in this study occurred in $Z$. aff. rosea with $2 n=25$, a trisome in this case, a phenomenon often observed in Zephyranthes. In a study involving 12 individuals from three different North American populations of Z. brazosensis, $2 n=48,55,56,58$, and 59 were observed (Coe 1954), while in Argentine populations of Z grandiflora, $2 n=23,24,36,48$, and $67+1 \mathrm{~B}$ also occurred (Greizerstein and Naranjo 1987). An extreme example of numerical variation is observed in $Z$. candida, with records of $2 n=38$ (this study), 24, 36, 38, 39, 40, 41, 42, and 49 (Table 1). These intraspecific polymorphisms are often related to the existence of cryptic species resulting from numerical or structural changes leading to formation of reproductive isolation barriers (Grant 1989). In an Argentinian population of this species, $2 n=38$ was observed in most individuals and $2 n=39$ in three others, due to the occurrence of trisomy in a smaller metacentric pair (Naranjo 1969). Aneuploidies are generally considered harmful, although in $Z$. aff. rosea and Argentine populations of $Z$. rosea, this additive trisomy seems to be at least neutral for these species. Aneuploid individuals are usually sterile by the formation of unbalanced gametes during meiosis. In Zephyranthes and related genera, it is likely that aneuploid cytotypes are maintained by asexual reproduction, as in Z. texana, a tetraploid species, where the megaspore mother cell does not undergo reductional division, originating directly an apomictic embryo (Brown 1951).

The wide numerical chromosome variation observed in Zephyranthes and Habranthus hinders the recognition of the primary base number of genera (Flory 1977). However, a quick analysis of numerical chromosome variation observed in the literature (Naranjo 1969; Greizerstein and Naranjo 1987; Flory and Smith 1980; Daviña 2001) makes it clear that most species of Zephyranthes and Habranthus have primary base number $x=6$; it is likely that disploid variations in the stock ancestor of these species have originated secondary base numbers $x=5,6,9,11,13$, and 15. Moreover, the frequent occurrence of higher numbers in this genus, as observed in this work for Z. grandiflora, $Z$. candida, and H. itaobinus, is derived from higher secondary numbers. From a strictly karyological point of view, it is difficult to infer phylogenetic relationships among species of these two genera based solely on chromosome numbers and morphology. A phylogenetic analysis broadened to a representative number of species of these two genera could contribute to understanding of the karyotypic evolution in this group of plants.

Chromosome sizes and basic karyotypic formulas are important tools for understanding the systematics and phylogeny in several plant groups (Bennett and Leitch 2005). In the genus Lapeirousia (Iridaceae), for example, mechanisms of centric fusion seem to have played a key role in differentiating karyotypes of L. avasmontana and $L$. coerulea, in this case a reduction of $2 n=16$ to $2 n=8$ followed by a reduction in asymmetry (Goldblatt 1990). On the other hand, in species of the genus Hippeastrum (Amaryllidaceae) native to South America, there seems to be a fair loss or gain in DNA amount that maintains the karyotype uniformity characteristic of the genus (Poggio et al. 2007). In Zephyranthes, where chromosome numbers are highly variable, there were no major differences in karyotype asymmetry. However, in species with higher numbers such as $Z$. candida and $H$. itaobinus, there seems to be a slight increase in karyotype asymmetry. In general, it is believed that more symmetric karyotypes and low chromosome numbers represent earlier stages in the evolution of a particular group of plants (Stebbins 1971). In Zephyranthes, however, the karyotype asymmetry does not play an important role in karyotype evolution of the genus.

Open Access This article is distributed under the terms of the Creative Commons Attribution Noncommercial License which permits any noncommercial use, distribution, and reproduction in any medium, provided the original author(s) and source are credited.

\section{References}

Alves-Araújo A, Santos FA, Alves M (2007) Caracterização palinológica de espécies de Amaryllidaceae sensu stricto ocorrentes no nordeste brasileiro. Acta Bot Bras 21:967-976

Bennett MD, Leitch IJ (2005) Nuclear DNA amounts in angiosperms: progress, problems and prospects. Ann Bot 95:45-90

Bougourd SM, Plowman AB, Ponsford NR, Elias ML, Holmes DS, Taylor S (1994) The case for unselfish B-chromosomes: evidence from Allium schoenoprasum. In: Brandham PE, Bennet MD (eds) Proceedings of the Kew chromosome conference IV. Royal Botanical Gardens, Kew, UK, pp 21-34

Bretagnolle F, Thompson JD (1995) Gametes with the somatic chromosome number: mechanisms of their formation and role in the evolution of autopolyploid plants. New Phytol 129:1-22

Brown WV (1951) Apomixis in Zephyranthes texana Herb. Am J Bot 38:697-702

Camacho JPM, Harbel TF, Beukeboom LW (2000) B-chromosome evolution, vol 355. The Royal Society, London, pp 163-178 
Coe GE (1954) Chromosome numbers and morphology in Habrathus and Zephyranthes. Bull Torrey Bot 81:141-148

Daviña JR (2001) Estudios citogeneticos en algunos generos argentinos de Amaryllidaceae. Teses, National University of Cordoba, Argentina

Daviña JR, Fernández A (1989) Karyotype and meiotic behavior in Zephyranthes (Amaryllidaceae) from South America. Cytologia, Tokyo 54:269-274

Dutilh JHA (2005) Ornamental bulbous plants of Brazil. Acta Hort 683:37-42

Dutilh JHA (2006) Amaryllidaceae. In: Barbosa MR, Sothes C, Mayo S, Gamarra-Rojas CFL, Mesquita AC (eds) Checklist das plantas do Nordeste Brasileiro: Angiospermas e Gymnospermas, MCT, Brasília

Dyer AE (1967) The maintenance of structural heterozygosity in Nothoscordum fragrans Kunth. Carylogia 20:287-308

Fedorov AMA (1974) Chromosome numbers of flowering plants. Komarov Bot Inst, Leningrad, Germany

Felix WJP, Dutilh JHA, Melo NF, Almeida A, Felix LP (2008) Intrapopulational chromosome number variation in Zephyranthes sylvatica Baker (Amaryllidaceae: Hippeastreae) from northeast Brazil. Rev Bras Bot 32:371-375

Flory WS (1977) Overview of chromosome evolution in the Amaryllidaceae. The Nucleus, Berlin 20:70-88

Flory WS, Smith GL (1980) High chromosome number in several Zephyrantheae taxa. Plant Life, Stanford Conn 36:63-72

Fregonezi JN (2004) The occurrence of different B in Cestrum intermedium and $C$. strigilatum (Solanaceae) evidenced by chromosome banding. Cytogenet Gen Res, New York 106: 184-188

Goldblatt P (1985) Index to plant chromosome number, vol 13. Miss Bot Garden, St. Louis

Goldblatt P (1990) Cytological variability in the African genus Lapeirousia (Iridaceae-Ixioideae). Ann Miss Bot 77:375-382

Goldblatt P, Johnson DE (1990) Index to plant chromosome numbers, vol 30. Miss Bot Garden, St. Louis

Goldblatt P, Johnson DE (1991) Index to plant chromosome numbers, vol 40. Miss Bot Garden, St. Louis

Goldblatt P, Johnson DE (1994) Index to plant chromosome numbers, vol 51. Miss Bot Garden, St. Louis

Grant V (1989) Especiación Vegetal. In: Herre EC, Garcia HED (eds). Noriega, Mexico, $587 \mathrm{p}$

Greizerstein EJ, Naranjo CA (1987) Estudios cromosomicos en especies de Zephyranthes (Amaryllidaceae). Darviniana, Buenos Aires 29:169-186

Guerra M (1983) Uso do Giemsa na citogenética vegetal, comparação entre a coloração simples e o bandeamento. Cien Cult 35: 190-193
Guerra MS (1986) Reviewing the chromosome nomenclature of Levan. Rev Bras Genet Ribeirão Preto 9:741-743

Houben A, Leach CR, Verlin D, Rofe R, Timmis JN (1997) A repetitive DNA sequence common to the different B chromosomes of the genus Brachycome. Chromosoma 106:513-519

Hutchinson J (2003) The families of flowering plants. Clarendon, Oxford

Jones N, Houben AB (2003) chromosomes in plants: escapes from the A chromosome genome? Trends Plant Sci 8:417-423

Judd WS, Campbell CS, Kellogg EA, Stevens PF (1999) Plant systematics: a phylogenetic approach. Sinauer, Massachusetts

Kai G, Lu Y, Qian ZYO, Luo N, Zhou G, Tang K (2006) Molecular characterization and expression analysis of a gene encoding mannose-binding lectin from bulb of Zephyranthes grandiflora. Biol Bratislava 61:671-677

Lorenzi H, Souza HM (1999) Plantas ornamentais no Brasil: arbustivas, herbáceas e trepadeiras. Instituto Plantarum, São Paulo

Moore RJ (1973) Index to plant chromosome number, vol 90. Regnum Vegetabile, Utrecht, Holland, pp 1-539

Moore RJ (1977) Index to plant chromosome number, vol 96. Regnum Vegetabile, Utrecht, Holland, pp 1-157

Naranjo CA (1969) Cariotipos de nueve especies argentinas de Rhodophiala, Hippeastrum, Zephyranthes y Habranthus (Amaryllidaceae). Kurtziana, Cordoba 5:67-87

Naranjo CA (1974) Karyotypes of four Argentine species of Habranthus and Zephyranthes (Amaryllidaceae). Phython, Argentina 32:61-71

Oliveira RS (2006) Flora da Cadeia do Espinhaço: Zephyranthes Herb. \& Habranthus Herb. (Amaryllidaceae)

Pang Y, Shen G, Qi H, Tan F, Sun X, Tang K (2004) Transgenic tobacco expressing Zephyranthes candida aglutinin showing enhanced resistance to aphids. Eng Life Sci 4:155-159

Plowman AB, Bougourd SM (1994) Selectively advantageous effects of B-chromosomes on germination behavior in Allium schoenoprasum $\mathrm{L}$. Heredity 72:587-593

Poggio L, González G, Naranjo CA (2007) Chromosome studies in Hippeastrum (Amaryllidaceae): variation in genome size. Bot $\mathrm{J}$ Linn Soc 155:171-178

Raina SN, Khoshoo TN (1971) Cytogenetics of tropical bulbous ornamentals VI: chromosomal polymorphism in cultivated Zephyranthes. Caryologia 2:217-227

Soltis DE, Soltis PS (1999) Polyploidy: recurrent formation and genome evolution. Tree 14:348-352

Stebbins GL (1971) Chromosomal evolution in higher plants. Addison-Wesley Publishing Company, California

Zarco CR (1986) A new method for estimating karyotipe asymmetry. Taxon 35:526-530 